\title{
繰返し曲げせん断力を受ける H 形断面梁の連成座屈挙動と塑性変形能力 COUPLED BUCKLING BEHAVIOR AND PLASTIC DEFORMATION CAPACITY OF H-SHAPED STEEL BEAMS UNDER CYCLIC BENDING SHEAR
}

\author{
五十嵐 規矩夫*, 末 國 良 太**, 鞆 伸 之*** \\ Kikuo IKARASHI, Ryota SUEKUNI and Nobuyuki TOMO
}

\begin{abstract}
In this research, in order to clarify the coupled instability behavior of $\mathrm{H}$-shaped steel beams under the bending shear stress, the cyclic loading tests was carried out, with a comparatively large web plate slenderness. As a result, the useful factor for coupled buckling design method of $\mathrm{H}$-shaped steel beams was proposed.

This method can treat systematically lateral buckling, local plate buckling and those coupled instability behavior. Its attention is paid to elastic lateral buckling strength and elastic plate local buckling strength. Characteristic of buckling behavior, coupled effect and range of coupled instability were clarified using both buckling strength ratio.
\end{abstract}

Keywords : H-shaped Beam, Cyclic Loading, Coupled Buckling, Plate Slenderness, Slenderness Ratio,

Plastic Deformation Capacity

H形断面梁，繰返し載荷，連成座屈，幅厚比，細長比，塑性変形倍率

1. 序

鋼構造建築物の部材では，座屈による不安定現象が設計上重要な 問題となる. H形断面部材の座屈性状は一般的に, 構成板要素の局部 座屈と部材全体の曲げねじり座屈に大別して考える場合が多く，日 本建築学会の規準 ${ }^{1)}$, 各指針2) 5), 技術解説書 ${ }^{6)}$ における設計式も これらは個別に扱われている，それぞれの座屈耐力算定式に基づい て, 局部座屈に対しては幅厚比, 曲げねじり座屈に対しては許容曲 げ応力度や細長比を指標とした各種寸法制限や塑性変形能力に応じ た構造区分が定められている.

近年では，ウェブ板厚を薄くした梁の耐震設計梁としての可能性 が論じられ 7)，8)，その局部座屈に対する有用な設計手法も確立しつ つある ${ }^{9), 10)}$.このようにウェブ板厚が薄い，あるいは梁せいが高い 梁を使用する際には，せん断応力度の影響が大きくなることに伴う ウェブの曲げせん断座屈の発生と, 弱軸方向の曲げ剛性が低くなる ことによる横座屈の発生を考虑することはもちろん, それらが複雑 に関連する連成座屈を考慮する必要がある，局部座屈，横座屈に関 する個々の研究成果の蓄積は多大であるものの, 局部座屈と横座屈 の連成を考慮した不安定問題に関する研究は少なく, その性状は十 分に明らかにされているとは言いがたい，したがって，現在，局部 座屈と横座屈が同時に発生する座屈現象としての連成不安定問題を 考慮した設計法は確立されていない。その特性を理解した上で効果
的に多様なH形断面梁を使用するためには, 最大耐力, 耐力劣化要因 の解明及び終局状態を局部座屈と横座屈の連成効果を考慮した上で 明らかにすることが必要となる.

局部座屈と横座屈の連成座屈を取り扱った研究は少ないものの, これまでにもいくつかの研究が行われている，興田らは連成座屈す る梁を対象とした繰返し載荷実験11)や降伏線理論に基づく解析を行 い, 局部座屈と横座屈のいずれが卓越するかの判定法や，局部座 屈，横座屈それぞれの場合の劣化勾配予測式を提案している ${ }^{12)}$. 鈴 木ら ${ }^{13)}$ は横座屈に対して広く用いられる一般化細長比と同様の考え 方を局部座屈の場合にも適用し，数値解析より得た局部座屈耐力か ら求めた一般化幅厚比との関係から座屈性状の判定を行い, 添接補 剛材により崩壊機構を制御することで安定した塑性変形性能を有す るH形鋼梁を実現できるとしている．小野ら ${ }^{14)}$ は部材中間部に横座屈 補剛材を有する細幅 $\mathrm{H}$ 形鋼梁について有限要素法解析を行い, 連成座 屈が発生する梁に対して鋼構造限界状態設計指針 ${ }^{4)}$ の各構造区分に 対応した必要補剛材性能について検討している。中島ら ${ }^{15)}$ は繰返し 曲げせん断力を受ける中間補剛されたH形断面梁について有限要素法 解析を行い, 連成座屈の発生する梁が十分な塑性変形能力を発揮で きる幅厚比制限值を与えている.

以上の研究はいずれも実験的, 数值解析的手法によるものであ る. 近年, 著者の一人は一連の研究 ${ }^{16)}, 17$ を通じてエネルギー法によ

\footnotetext{
* 東京工業大学大学院理工学研究科建築学専攻 准教授・博士 (工学)

** 東京工業大学大学院理工学研究科建築学専攻 大学院生・修士 (工学)

(現 日建設計)

*** 東京工業大学大学院理工学研究科建築学専攻 大学院生
}

Assoc. Prof., Dept. of Arch. and Build. Eng., Tokyo Institute of Technology, Dr. Eng.

Graduate Student, Dept. of Arch. and Build. Eng., Tokyo Institute of Technology, M. Eng.

Graduate Student, Dept. of Arch. and Build. Eng., Tokyo Institute of Technology 
る理論解析から曲げせん断力及び軸力を受けるH形断面部材の連成効 果を考慮した精度の高い連成座屈耐力式を導出しており, 連成座屈 に関する座屈耐力決定因子がある程度解明されている。 また，これ らの成果を用いて局部座屈する梁を対象とした塑性変形能力評価を 行ったものとして文献 9)，10）があり，簡便かつ精度よく塑性変形 能力を評価している.

H形断面梁の耐震性能を考える上で, 繰返しによる影響を把握する ことは重要である. 鋼構造部材の繰返し載荷と単調載荷の関係とし て, 加藤らが文献18)などで提唱した経験則がある ${ }^{20)}$. 繰返し荷重を 受ける部材の塑性変形能力は骨格曲線換算で考えることが多いた め, その復元力特性を把握するために局部座屈を伴う部材の単調載 荷履歴モデルも提案されている ${ }^{19)}$. 文献 5 ) には部材の繰返し載荷履 歴と局部座屈挙動あるいは横座屈挙動との関係を調べた研究より得

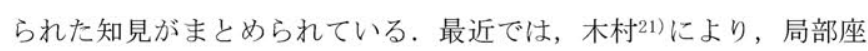
屈で崩壊するH形断面梁の最大耐力時の塑性変形倍率や累積塑性変形 倍率に与える影響因子についてまとめられ, その推定式が提案され ている. 繰返し荷重下で横座屈する梁については, 井戸田ら ${ }^{22)} に よ$ り, 単調載荷履歴モデルとの対応を明らかにした上で, 詳細な繰返 し履歴モデルが提案されている.

以上のような背景のもと, 本研究では, 比較的ウェブ幅厚比の大 きなH形断面梁を対象として繰返し載荷実験を行い, 曲げせん断力を 受けるH形断面梁の連成座屈挙動を明らかにする. その結果を用い て, 現行の各種設計法においては独立に扱われている横座屈と局部 座屈及びそれらの連成までを考慮した統一的な設計法に有用な部材 性能評価指標を提案することを目的としている. 複雑な連成座屈現 象を考える上で連成局部座屈耐力と横座屈耐力に着目し, 両者を比 較することで卓越する座屈性状の判定, 大変形領域における連成効 果について考察を加える. さらに数值解析結果及び既往の実験結果 から局部座屈耐力と横座屈耐力の座屈耐力比を指標として連成効果 を考える必要のある範囲を検討する，そこで得られた知見をもとに 連成座屈を考虑した新たな指標を提案した上で, H形断面梁の連成座 屈を考慮した塑性変形能力評価法の提案を行う。

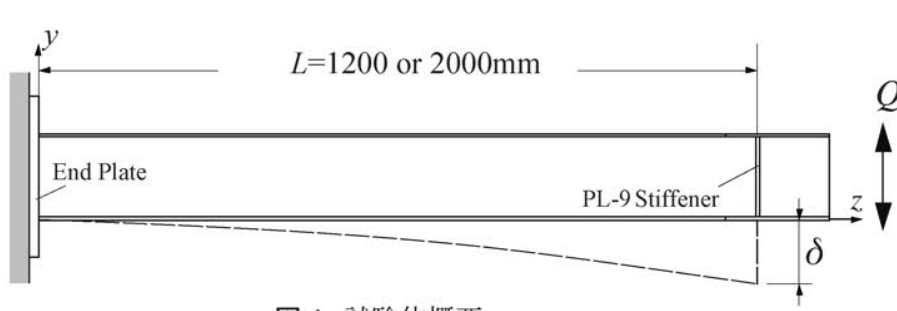

図 1 試験体概要

\section{2. 連成座屈を生じるH形断面梁の繰返し性状 2.1 繰返し載荷試験体及び実験概要}

本実験では，片持ち梁形式のH形断面梁を対象に，端部境界条件は 一端完全固定, 他端単純支持を想定し, 材長途中では面外変位を拘 束しない繰返し載荷実験を行った。試験体は図 1 に示すような, 溶 接組立H形断面梁である.フランジとウェブは両面隅肉溶接により接 合している. 固定端側にエンドプレートを設け，フランジを完全溶 込み溶接, ウェブを隅肉溶接により接合している. 他端は面外単純 支持を再現するため, 図 2 に示寸加力治具をボルトで取付けた上 で, 治具の面外方向変位を拘束している.この端部面外回転許容治 具は, 内蔵されたベアリングによって端部が回転可能であり, 上下 梁フランジの面外回転を個別に許容する機構とし, 断面のそりを拘 束しない仕組みとしている.この載荷部における機構の詳細につい ては, 付録 1 に示している. なお, 載荷点位置にスチフナを配して いるものの, この程度のスチフナでは端部拘束の影響は小さい23) と 判断した.

載荷履歴は, 正負交番変位漸増繰返し載荷とし, 載荷点梁端部変 位 $\delta$ に対し, 変位制御で $\delta_{b}$ を 3 回, その後 ${ }_{b} \delta_{p}, 2_{b} \delta_{p}, 3_{b} \delta_{p}, \cdots \cdot$ 一 3 回ずつ繰返し, 十分耐力が低下するまで続けた. ここで $b \delta_{y}, b \delta_{p}$ は それぞれ降伏モーメント $M_{y}$, 全塑性モーメント $M_{p}$ に対する曲げ変形 のみを考慮した弾性変位である. 表 1 に使用した鋼材の機械的性質 を示す. 降伏応力度は, $6 \mathrm{~mm}, 9 \mathrm{~mm}$ 厚の板については下降伏点を用 い, 明確な上下降伏点を持たなかった $2.3 \mathrm{~mm}, 3.2 \mathrm{~mm}, 4.5 \mathrm{~mm}$ 厚の板に ついては，0.2\%オフセット耐力を用いている.

表 2 に各試験体の諸元を示す. 表中の值は実測值を用いて算出し ている. $、$ は断面内に生じる曲げとせん断応力の比率を表すものであ り, 式(2.3)による.WFは, 文献 9)，10）で提案されているもので あり, H形断面梁に生じる応力分布を考慮した上で, フランジとウェ ブの連成局部座屈耐力式から求めた基準化幅厚比である. $\lambda_{b}$ は本実 験での端部境界条件及び曲げモーメント分布をもとに, 文献24)に示

表 1 鋼材の機械的性質

\begin{tabular}{|c|c|c|c|c|c|c|}
\hline 板厚 & 降伏応力度 引張強さ & ヤング係数 & 一椂伸び & 伸び & 降伏比 \\
\hline $\begin{array}{c}\mathrm{t} \\
(\mathrm{mm})\end{array}$ & $\begin{array}{c}\sigma_{y} \\
\left(\mathrm{~N} / \mathrm{mm}^{2}\right)\end{array}$ & $\begin{array}{c}\sigma_{u} \\
\left(\mathrm{~N} / \mathrm{mm}^{2}\right)\end{array}$ & $\begin{array}{c}E \\
\left(\mathrm{~N} / \mathrm{mm}^{2}\right)\end{array}$ & $\varepsilon_{u}$ & $\begin{array}{c}E l n g . \\
(\%)\end{array}$ & $Y . R$. \\
\hline 2.3 & 221 & 334 & 191000 & 20.4 & 30.5 & 0.66 \\
\hline 3.2 & 275 & 431 & 219000 & 19.3 & 31.4 & 0.64 \\
\hline 4.5 & 288 & 431 & 211000 & 19.7 & 29.4 & 0.67 \\
\hline 6.0 & 292 & 428 & 205000 & 19.4 & 30.2 & 0.68 \\
\hline 9.0 & 272 & 421 & 209000 & 22.7 & 31.4 & 0.65 \\
\hline
\end{tabular}

表 2 試験体緒元

\begin{tabular}{|c|c|c|c|c|c|c|c|c|c|c|c|}
\hline & Section & $\begin{array}{c}L \\
(\mathrm{~mm})\end{array}$ & $d / t_{w}$ & $b / t_{f}$ & $\begin{array}{c}M_{p} \\
(\mathrm{kN} \cdot \mathrm{m})\end{array}$ & $\begin{array}{c}b \delta_{y} \\
(\mathrm{~mm})\end{array}$ & $\begin{array}{c}b \delta_{p} \\
(\mathrm{~mm})\end{array}$ & $\begin{array}{c}\delta_{p} \\
(\mathrm{~mm})\end{array}$ & $\alpha$ & $W F$ & $\lambda_{b}$ \\
\hline No.1 & H- $190 \times 72 \times 2.3 \times 9$ & 1200 & 81 & 3.9 & 36.2 & 6.7 & 7.0 & 8.2 & 0.274 & 0.70 & 0.29 \\
\hline No.2 & H- $190 \times 72 \times 2.3 \times 9$ & 2000 & 80 & 3.8 & 37.6 & 18.6 & 19.3 & 20.6 & 0.169 & 0.62 & 0.45 \\
\hline No.3 & H- $190 \times 72 \times 3.2 \times 6$ & 1200 & 60 & 6.1 & 28.6 & 7.3 & 7.9 & 8.5 & 0.140 & 0.60 & 0.34 \\
\hline No.4 & H- $190 \times 72 \times 3.2 \times 6$ & 2000 & 58 & 6.0 & 29.3 & 20.2 & 21.8 & 22.7 & 0.083 & 0.59 & 0.55 \\
\hline No.5 & H- $190 \times 80 \times 4.5 \times 9$ & 2000 & 40 & 4.2 & 45.9 & 19.0 & 20.5 & 21.3 & 0.098 & 0.40 & 0.44 \\
\hline No.6 & H- $190 \times 90 \times 2.3 \times 9$ & 2000 & 77 & 4.8 & 45.2 & 18.7 & 19.3 & 20.9 & 0.199 & 0.64 & 0.37 \\
\hline No.7 & H- $190 \times 120 \times 4.5 \times 9$ & 2000 & 41 & 6.5 & 62.4 & 19.0 & 20.1 & 21.3 & 0.139 & 0.48 & 0.30 \\
\hline No.8 & H- $240 \times 90 \times 2.3 \times 9$ & 2000 & 109 & 4.8 & 57.8 & 14.6 & 15.2 & 16.8 & 0.219 & 0.88 & 0.39 \\
\hline No.9 & H- $240 \times 90 \times 4.5 \times 6$ & 2000 & 51 & 7.4 & 53.6 & 16.0 & 17.8 & 18.5 & 0.078 & 0.60 & 0.48 \\
\hline
\end{tabular}




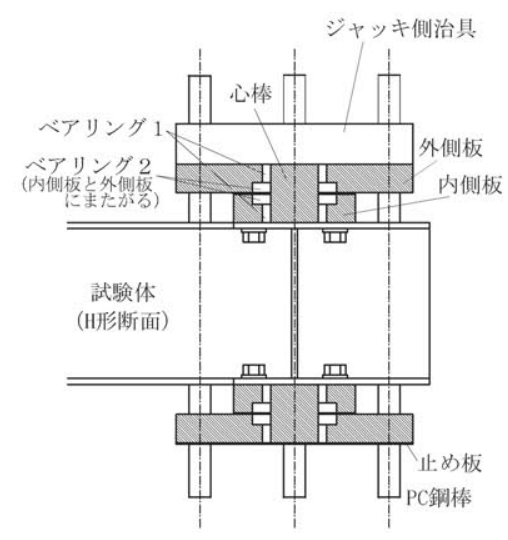

図 2 載荷点治具

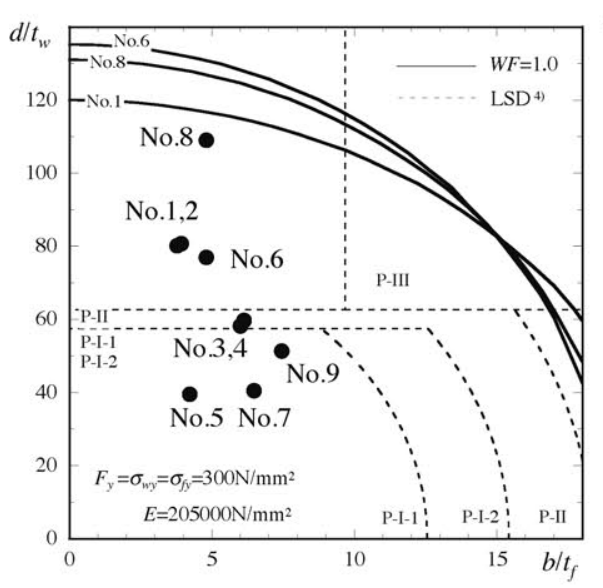

図 3 試験体幅厚比

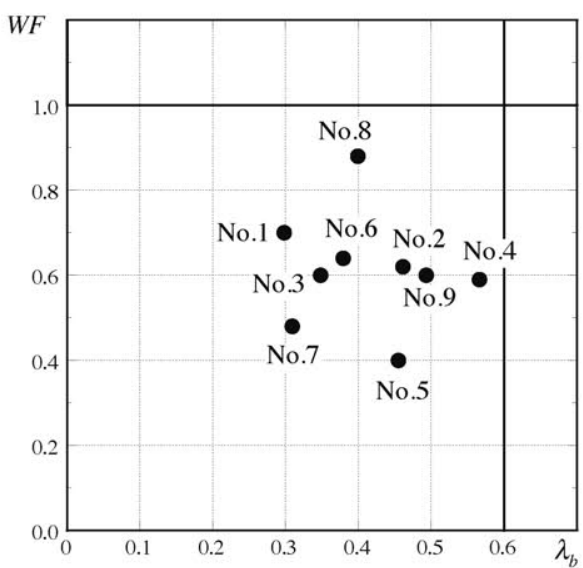

図 4 試験体の $W F-\lambda_{b}$ 関係
されている方法により個別に定めた一般化横座屈細長比である. WF については式(2.1)〜 (2.3)で， $\lambda_{b}$ についてはその近似值が，式(2.4) 〜 (2.8)で表される.

WFについては,

$$
\begin{aligned}
& W F=\sqrt{\frac{1}{k^{2}}\left(\frac{d / t_{w}}{\sqrt{E / \sigma_{y w}}}\right)^{2}+\left(3.43-\frac{25.0}{k^{2}}\right)\left(\frac{b / t_{f}}{\sqrt{E / \sigma_{y f}}}\right)^{2}} \quad \cdots(2.1) \\
& \text { ここで, } \\
& k=\left\{\begin{array}{lr}
4.4 & \alpha<1 / 6 \\
5.18-4.6 \alpha & 1 / 6 \leq \alpha \leq 1 / 2 \\
2.9 & \alpha>1 / 2
\end{array}\right. \\
& \alpha=\left(\frac{1}{6}+\frac{A_{f}}{A_{w}}\right) \frac{\beta}{\lambda_{w}} \quad \ldots \ldots \ldots
\end{aligned}
$$

式(2.1)〜 (2.3)の各記号は, $\sigma_{y w}$ : ウェブ降伏応力度, $\sigma_{y f}$ : フランジ 降伏応力度, $E$ : ヤング係数, $d:$ ウェブせい, $t_{w}$ : ウェブ板厚, $b$ : フランジ半幅, $t_{f}$ : フランジ板厚, $A_{w}$ : ウェブ断面積, $A_{f}:$ フランジ 断面積, $\lambda_{w}$ : ウェブ辺長比, $\beta$ : 曲げ応力勾配 $(0 \leq \beta \leq 2,0$ : 均等曲 げ，2: 逆対称曲げであり，本論文では 1$)$ である.

$$
\begin{aligned}
& \lambda_{b} \text { にいては, } \\
& \lambda_{b}=\sqrt{\frac{M_{p}}{M_{c r}}} \\
& \text { ここで, }
\end{aligned}
$$

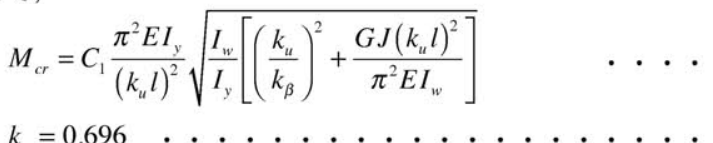

$$
\begin{aligned}
& k_{\beta}=0.696 \ldots \ldots \ldots \ldots \\
& C_{1}=\frac{1+\left(-0.200 \beta+0.476 \beta^{2}-0.179 \beta^{3}\right) /\left(1+0.113 \frac{G J l^{2}}{\pi^{2} E I_{w}}\right)}{1-0.548 \beta-0.197 \beta^{2}+0.178 \beta^{3}}
\end{aligned}
$$

式 $(2.4) \sim(2.8)$ の各記号は, $M_{p}$ : 梁の全塑性モーメント, $M_{c r}$ : 梁の 弾性横座屈モーメント, $C_{1}$ : モーメント修正係数, $I_{y}$ : 弱軸まわりの 梁の断面 2 次モーメント, $I_{w}$ : 梁の曲げねじり定数, $J$ : 梁のねじり 定数, $l$ : 梁の支点間長さ, $k_{u}$ : 弱軸曲げに対する座屈長さ係数, $k_{\beta}$ : 曲げねじりに対する座屈長さ係数, $E$ : ヤング係数, $G$ : 横弾性 係数, $\beta$ : 曲げ応力勾配 $(0 \leq \beta \leq 2,0$ : 均等曲げ, 2 : 逆対称曲げであ り, 本論文では 1 )である.

図 3 に各試験体の幅厚比関係を示す．図中実線で示す曲線が試験 体No. 1，6，8に対応する $W F=1.0$ とした時の制限曲線10)である. この 曲線は, 各板要素に対応寸る引張試験から得られた表 1 に示寸素材 の材料定数を考虑して求めたものである.また破線が鋼構造限界状 態設計指針4)に示されている幅厚比区分である。この制限值は，降 伏応力度を $300 \mathrm{~N} / \mathrm{mm}^{2}$, ヤング係数を $205000 \mathrm{~N} / \mathrm{mm}^{2}$ として定めたもので ある.ここで, 試験体No. 8のウェブ幅厚比は, 鋼構造限界状態設計 指針4)の制限值を満たすものではないが，文献10)における $W F=1.0$ の制限值を満たしているため, 端部モーメントが全塑性モーメント を確保できる試験体である. 同様に, 試験体No. 1，2，6について も，全塑性モーメントを確保することができる.

図 4 に各試験体の $W F-\lambda_{b}$ 関係を示寸. WFについては, 前述した通 り, 全て 1 以下である. また, $\lambda_{b}$ については0.6以下となっている. 鋼構造限界状態設計指針 ${ }^{4}$ ) に従えば, 本試験体のように横座屈支持 区間の両端の曲げモーメント比が $0 （$ 本論文の表記では, $\beta=1 ）$ の場 合, 塑性限界細長比は 0.6 となる。したがって, 本論文における試験 体は，弾性横座屈は発生せず，全塑性モーメントを確保できる．図 に示すように, 本論文で対象とする試験体は, $\lambda_{b}$ - WF 平面上に広く分 布している.

\section{2 繰返し曲げせん断力を受けるH形断面梁の連成座屈挙動}

図 5 に繰返し載荷実験より得られた全試験体の荷重変位関係を示 す. 各荷重変位関係には, 荷重方向別の最大耐力点を $\mathbf{2} て ゙$ 示, 観 測された座屈発生点を現象別に示している.この座屈発生点は, 局 部座屈に関しては，目視あるいは板要素両面に貼付したひずみゲー ジの值の差が急激に増大したループの除荷点とし, 横座屈に関して は, 材長の $1 / 2$, 固定端側から材長の $1 / 4$ の位置に設置した変位計よ り計測した上下フランジ位置の横たわみが, 初めて材長の $1 / 200$ を超 えた点としている. 図 6 には, 固定端側から材長の $1 / 4$ の下フラン ジ位置での面外変位量を材長で除し, 載荷ステップの進行とともに 示す. 荷重正方向時に圧縮側及び引張側になるフランジの面外変位 量をそれぞれ $u_{1}$ 及び $u_{2}$ で示している. 図中のmax+, max-はそれぞれ 荷重正方向時の最大耐力時, 荷重負方向時の最大耐力時を示してい 


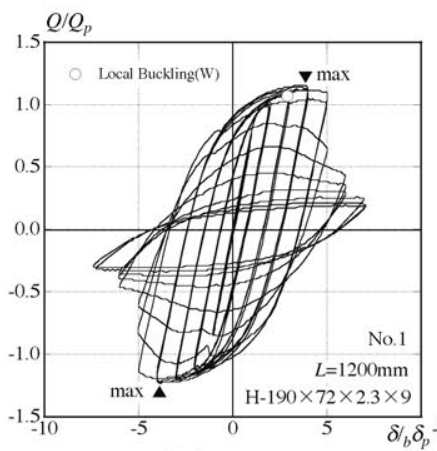

(5a) No. 1

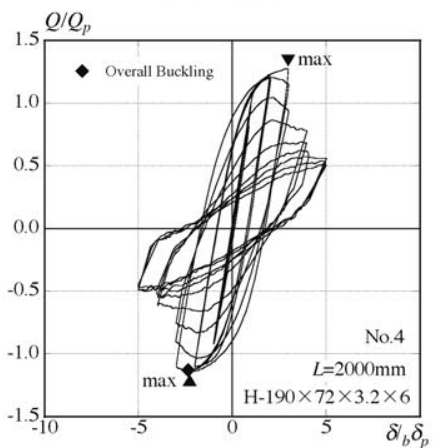

(5d) No. 4

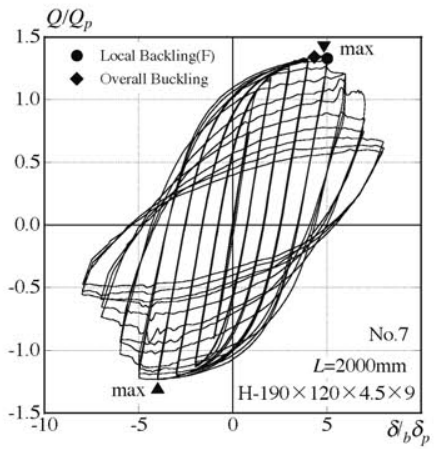

(5g) No. 7

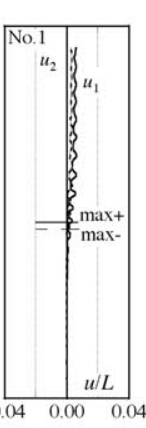

(6a) No. 1

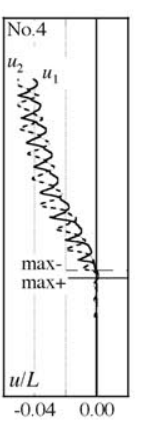

(6d) No. 4

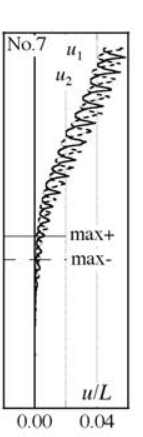

(6g) No. 7

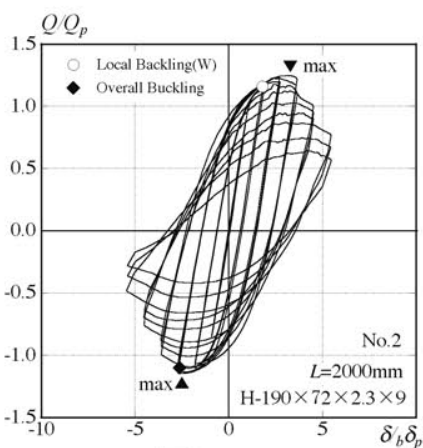

(5b) No. 2

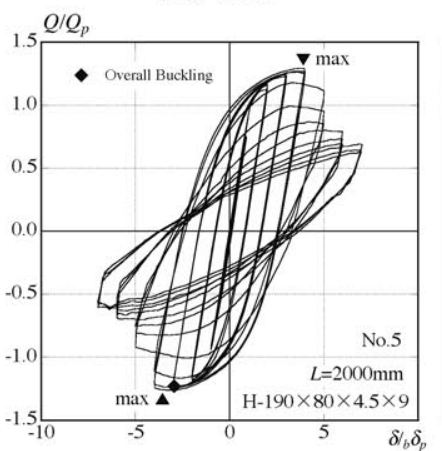

(5e) No. 5

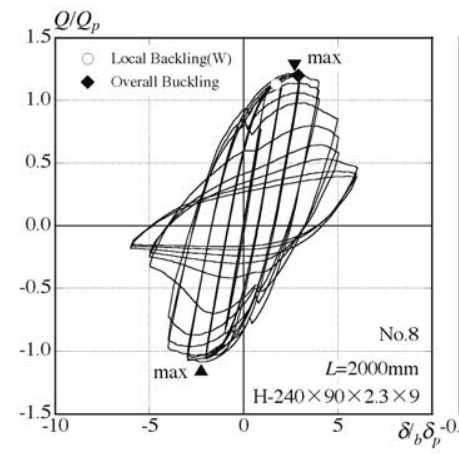

(5h) No. 8

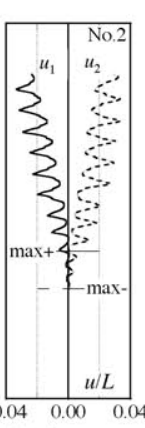

(6b) No. 2

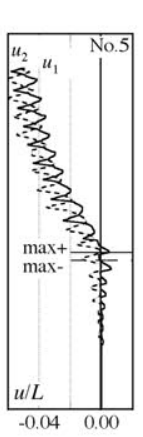

(6e) No. 5

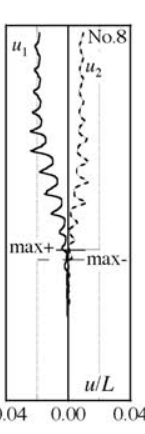

(6h) No. 8

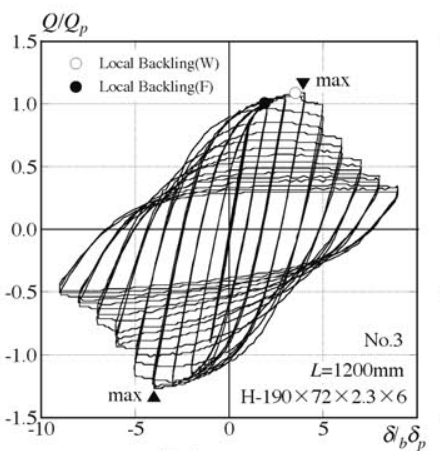

(5c) No. 3

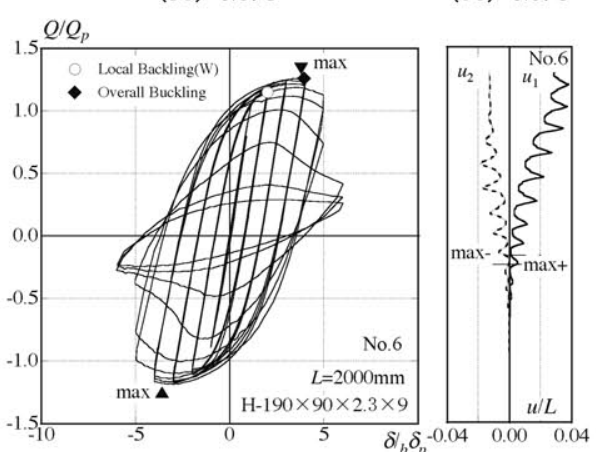

(5f) No. 6

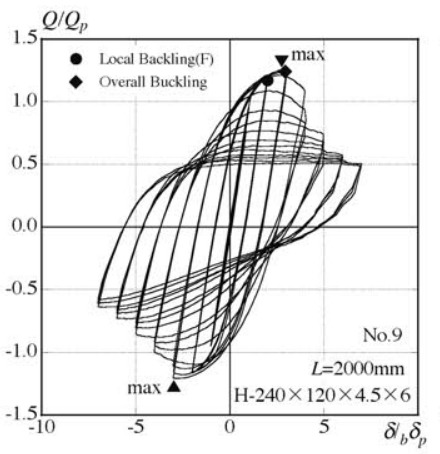

(6f) No. 6

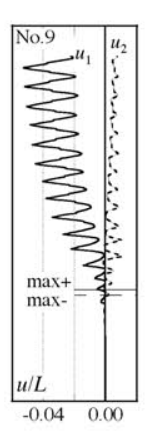

(6i) No. 9

図 5 全試験体の荷重変位関係 及び 図 6 全試験体の面外変形性状（註 : 上図で各試験体毎に左が図 5 , 右が図 6 である.）

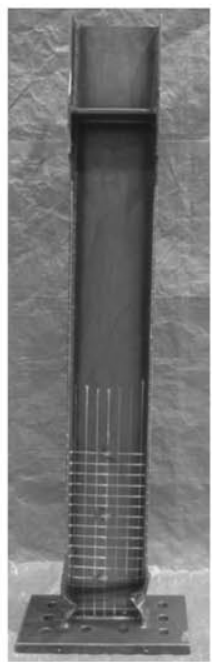

写真 1 局部座屈 変形 (No. 3)
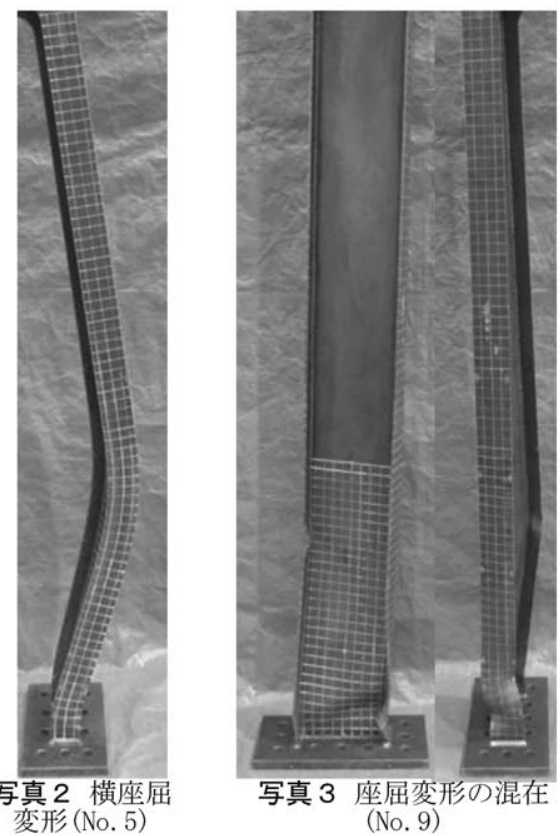

写真 3 座屈変形の混在 (No. 9)
表 3 各試験体の崩壊形式と骨格曲線による塑性変形倍率一覧

\begin{tabular}{|c|c|c|c|c|c|c|}
\hline & $W F$ & $\lambda_{b}$ & $\kappa$ & Mode & $\mu_{c s}+$ & $\mu_{c s^{-}}$ \\
\hline No.1 & 0.70 & 0.29 & 2.39 & Local(W) & 5.21 & 4.62 \\
\hline No.2 & 0.62 & 0.45 & 1.38 & Coupled(W+O) & 3.30 & 2.59 \\
\hline No.3 & 0.60 & 0.34 & 1.77 & Local(F) & 3.88 & 5.76 \\
\hline No.4 & 0.59 & 0.55 & 1.07 & Overall & 2.22 & 2.91 \\
\hline No.5 & 0.40 & 0.44 & 0.90 & Overall & 5.23 & 4.58 \\
\hline No.6 & 0.64 & 0.37 & 1.72 & Coupled(W+O) & 3.94 & 4.58 \\
\hline No.7 & 0.48 & 0.30 & 1.60 & Coupled(O+F) & 5.06 & 5.01 \\
\hline No.8 & 0.88 & 0.39 & 2.27 & Coupled(W+O) & 2.40 & 2.02 \\
\hline No.9 & 0.60 & 0.48 & 1.25 & Coupled(F+O) & 2.29 & 2.93 \\
\hline
\end{tabular}

る.なお図 5 , 図 6 は各試験体ごとに並べて示している. 写真 1 3 には, 特徵的な崩壊形式の例を示している. 表 3 には, 各試験体 の崩壊モード, 3 章で示す塑性変形倍率の值及び $\kappa^{\prime} W F / \lambda_{b}$ を示してい る.ここで塑性変形倍率 $\mu_{c s}+, \mu_{c s}$-は， 3 章に示す方法により骨格曲 線を作成した後, それぞれ正方向載荷, 負方向載荷における最大荷 重時の変位量から算出している，崩壊モードの中で記号W，F，Oは それぞれウェブ局部座屈, フランジ局部座屈, 横座屈を示してお り，+はそれらが複合した崩壊モードであることを示している. 


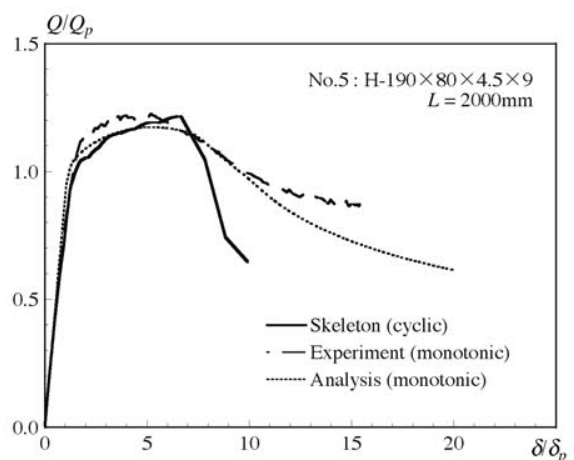

(a) No. 5

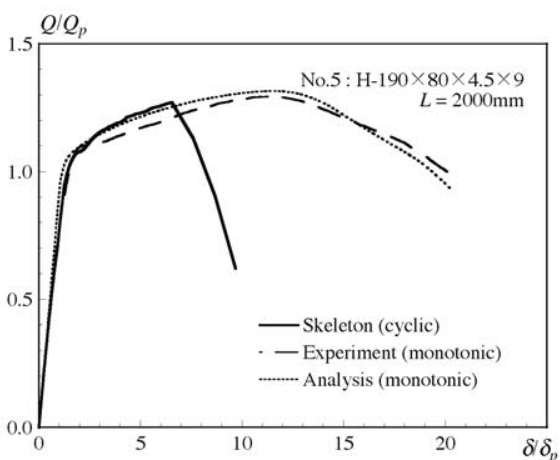

(b) No. 7

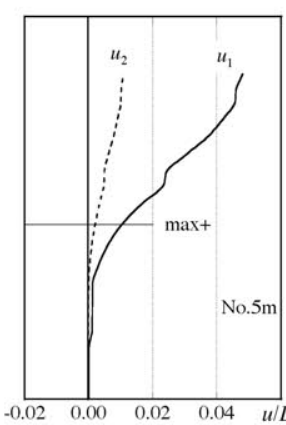

(a) No. 5

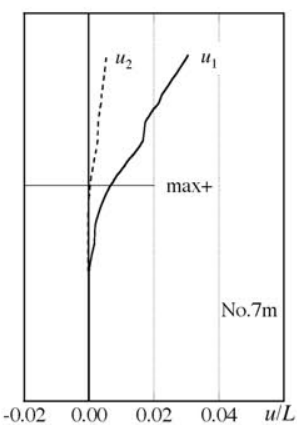

(b) No. 7

図 7 骨格曲線の比較

全体的な傾向としては，いずれの試験体も全塑性曲げ耐力を確保

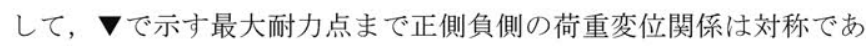
り, 安定した紡鍾型の履歴曲線となっている. 最大耐力以降は, 各 試験体で異なった崩壊形式となり, 荷重変位関係は耐力劣化ととも に崩れていく. また耐力劣化の程度も異なっている.

さらに崩壊形式に着目して以下にまとめる. No.1はウェブ局部座 屈, No. 3はフランジ局部座屈が主要因となり崩壊し, 目立った横変 位はない. No. 4, No. 5 は衫じれを伴わない弱軸方向の曲げが支配的 な横座屈で崩壊している.これに対して, No.2は, 弱軸方向の曲げ 変形がなく, ねじれが支配的な崩壊である.これら, No. 2 と No. 4 , No. 5 の面外変形性状の違いは, 図 6 の (6b) と (6d), (6e) に違いと なって現れている. 写真 1 , 写真 2 にそれぞれフランジ局部座屈と 横座屈の例としてNo. 3, No. 5の最終変形状態を示す.

No. 6, No.8はウェブ局部座屈と横座屈が, No. 7, No.9はフランジ 局部座屈と横座屈が連成している. No. 6 , No.7は最大耐力以降も正 負で対称な履歴曲線を描いているのに対し, No. 8, No.9ではその履 歴が正負で非対称となっている，これは，図 6 に示す面外変形性状 にも良く現れており, No.6は㸚じりが進行する形式, No.7は弱軸曲 げが進行する形式ではあるが， $u_{1}, u_{2}$ で絶対值がほぼ等しい進行状況 である.これに対して, No. 8, No.9のものは異なる進行状況であ り， $u_{1}$ の進行のみが相対的に大きい.

この非対称な座屈変形は最大耐力後の劣化性状に大きな影響を及 ぼし，劣化性状は正側負側それぞれに対して圧縮側となるフランジ の座屈性状に大きく左右される. No. 8は正側で横座屈を生じた試験 体No. 5 と同様の劣化性状を示す一方, 負側でNo. 6 と同様の劣化性状 を示している. No. 9についても正側でNo. 5 に類似の横座屈の特徴, 負側でNo. 3 に類似のフランジ局部座屈の特徵を示している. 写真 3 にNo. 9の最終変形状態を示す. 正側で圧縮側となるフランジ（右側 写真の奥側フランジ, 左側写真の左側フランジ) が横座屈とフラン ジ局部座屈の連成座屈を生じているのに対し, 負側で圧縮を受ける フランジ（右側写真の手前フランジ，左側写真の右側フランジ）は 端部のフランジ局部座屈が主要な座屈モードとなっている.このよ うに梁の繰返し載荷に特有の現象として, 構成板要素の局部座屈と 横座屈が正側, 負側の荷重時で別々に発生する場合があり，正負で 非対称な座屈変形を生じる.ただし, 前に述べたように最大耐力点 までの履歴曲線の形状は対称である.

このように，局部座屈と横座屈が同時に起こるような梁は大変複 雑な崩壊挙動を示すため, 単に局部座屈指標や横座屈指標で梁の性
能を評価するのは困難であり，それらを複合的に考慮した新たな指 標が必要である. 以下では, この崩壊形式の分類を行った上で, 連 成座屈が発生する梁の塑性変形能力評価を行う.

\section{3. 連成座屈を考慮したH形断面梁の塑性変形能力評価 3.1 繰返し載荷結果と一方向単調載荷結果の相違}

本論文では，履歷の違いが荷重変位関係に及ぼす影響の確認と数 值解析との対応を見ることを目的に, 一方向単調載荷による載荷実 験も行っている. 一方向単調載荷を行った試験体は, No. 5 , No. 7 と 同一のものである. 図 7 に文献20) に示されている方法により繰返し 載荷の結果から抽出した曲線, 一方向単調載荷による結果, 数值解 析から得られた結果を比較したものを示す．なお繰返し載荷の結果 は, 最大耐力点までは荷重の更新点を結んだ骨格曲線に, 最大耐力 以降は, 各変位振幅における 1 サイクル目の除荷点を結んだ包絡線 に変換した曲線で示している．数值解析には汎用有限要素法プログ ラムABAQUSを用いた４節点シェル要素を用いて解析モデルを作成 し, 固有值解析から得られた固有値の小さい方から 2 つに対応寸る 固有モードを足し合わせて初期不整を与え, 弾塑性大変形解析を 行っている. 材料特性は, 板要素ごとに引張試験より得られた応力 度ひずみ度関係を用いている. これら数值解析の詳細については, 付録 2 に示している. 図 7 に示寸ように, No. 5, No.7とも一方向載 荷の荷重変位関係と数值解析結果は良く一致している。

図 7 (a) に示すNo. 5は一方向単調載荷の荷重変位関係と繰返し載荷 より得られた骨格曲線は良く一致している. 図 7 (b) に示すNo. 7の場 合は塑性変形能力が大きいため, 骨格曲線の最大耐力時変位量が一 方向単調載荷のものにくらべ小さい. 塑性変形能力が比較的小さい 梁の一方向単調載荷の荷重変位関係々骨格曲線は比較的良く一致す るものの, 塑性変形能力が大きな梁の場合の両者は骨格曲線から得 られるものが小さい傾向にある10)。これは繰返し載荷によるエネル ギー吸収量の違いによるものであると推測される.

また, 先の図 5 (5e) に示すNo. 5を繰返した場合の最大耐力以降の 耐力劣化は, 図 7 (a)の一方向載荷の場合より急激である.これは, 図 8 に示寸一方向載荷の場合の面外変形の進展の様子と図 $6(6 \mathrm{e})$ の 繰返し載荷の場合の面外変形の進展の様子を比較する事で説明でき る. 一方向単調載荷の場合は, 圧縮側フランジの材に対する面外変 位のみが比較的大きくなっているのに対して, 繰返し載荷の場合は 両フランジの材に対する面外変位が同程度に大きくなっている.こ のため一方向単調載荷の場合は, 繰返し載荷の場合に比較して引張 
側フランジの抵抗が大きく，耐力劣化勾配が緩やかになる.

なお, No. 5 は横座屈による崩壊, No. 7 は局部座屈と横座屈の連成 による崩壊であり, これら試験体の最終崩壊形式は異なるものの, 数值解析により得られた崩壊形式はそれぞれで概ね一致していた. このことから, 先の荷重変位関係及び最終崩壊形式ともに数值解析 により再現可能と判断できる.

\section{2 連成座屈範囲の特定と連成効果による塑性変形倍率への影響}

前章の表 3 に示した載荷実験結果に見るように, H形断面梁の崩壊 形式は, 構成板要素の局部座屈, 横座屈, それらの連成座屈の 30 に大別されることが明らかになった. 数值解析結果も含めて, 基準 化幅厚比 $W F$ と一般化横座屈細長比 $\lambda_{b}$ からなる平面に崩壊形式を示し たものが図 9 である。 $\square$ 品局部座屈,

○, ○が横座屈, $\boldsymbol{\Delta}, \triangle$ が連成座屈を表し, 黒プロットが実験結果, 白プロットが数值解析 結果である.これら崩壊形式の判断は目視による. なお, 図中の直 線の傾きの具体的な数值の意味は後述するが，この結果をもとに， おおまかには直線の傾きが 2.4 以上の範囲は局部座屈, 概ね 20.9 以下 の範囲では横座屈のみを生じている. その中間の 0.9 から 2.4 の間で は連成座屈が発生する可能性のある範囲として区分できる．ただ し, 実際の座屈性状は幅厚比や断面積比, 板幅比等の個別の形状因 子が複雑な相互作用を及ぼすために，今回連成座屈範囲と定めた範 囲においても局部座屈や横座屈が単独で発生していると見なせる座 屈性状の試験体もあり，この範囲に存在する試験体全てに連成座屈 が生じるというわけではないことに注意する必要がある。ただ，連 成座屈が発生する可能性がある範囲を定めるものとして, $W F$ と $\lambda_{b}$ の 比は有用であると考える。ここでこの比を式 $(3.1)$ のように る. 本論文で行った載荷実験の試験体のאの值は表 3 に示している.

$$
\kappa=\frac{W F}{\lambda_{b}} \ldots \ldots \ldots \ldots \ldots \ldots
$$

ここで, $W F:$ 式(2.1) で与えられる值, $\lambda_{b}:$ 式(2.4)で与えられる值 である。

なお，この現象と同様な現象を著者の一人は文献16)の中で弾性座 屈耐力の考察から捉えている. H形断面梁で局部座屈耐力と横座屈耐 力が近接する場合, その連成座屈耐力は, 局部座屈耐力あるいは横 座屈耐力のどちらか低い耐力よりも低下する.この現象は, 横座屈 と局部座屈の連成効果によるものである. 本論文では, 全塑性耐力 後の崩壊モードを検討しているものであり, 直接比較できるもので はないが， $\kappa$ がある範囲において連成座屈モードで崩壊することと何

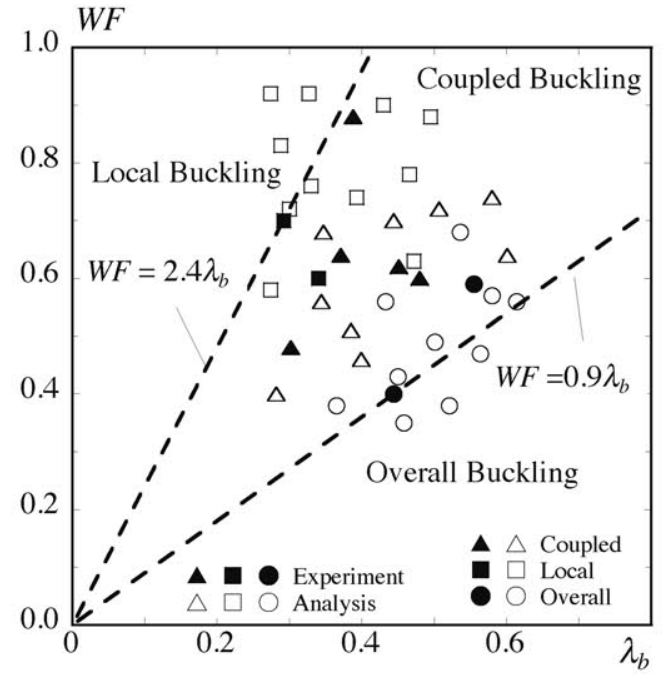

図 9 崩壊形式の分類

らかの因果関係があると推察できる.

図 9 において連成座屈範囲の境界を与える 方法を以下に示寸．梁の曲げねじれ変形を拘束した場合，梁の塑性 変形能力は局部座屈性状のみによって決定されると考えてよい，梁 の曲げねじれ変形を拘束しない場合は, 曲げねじれ変形の影響によ り塑性変形能力は低下し, 梁の曲げねじれ変形を拘束せずとも構成 板要素の幅厚比が大きい場合には, 局部座屈により梁の塑性変形能 力が決定することは容易に想像がつく，ここでは，曲げねじれ変形 の拘束の有無が, 梁の塑性変形能力に影響を及ぼす範囲について数 值解析的に検討する.

図10は, 曲げねじれ変形を拘束しない場合の塑性変形倍率に対寸 る拘束した場合の塑性変形倍率の比を縦軸に, 横軸に $\kappa$ をとったもの である.この図において綎軸の值が 1 となった場合，最大耐力決定 要因が局部座屈のみで決定すると捉えられる. 図中のプロットは数 值解析結果であり, ○は 2 章で行った試験体に対応したものであ る. 解析範囲は, $W F$ で約 0.3 から $0.9, \lambda_{b}$ で約 0.2 から 0.6 の範囲を検 討対象としている. 図より 拘束による塑性変形倍率の増大はなく, 拘束による効果は得られな い.つまり最大耐力決定要因が横座屈が関連する連成座屈ではな く, 局部座屈のみで決まると判断できる. まずこの知見から, 局部 座屈のみで塑性変形能力が決定する範囲を $\kappa>2.4$ として定める.

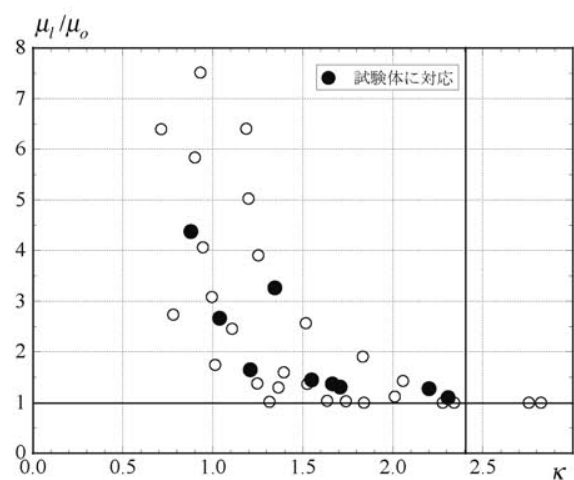

図10 曲げねじれ変形の拘束が塑性変形倍率 に及ぼす範囲

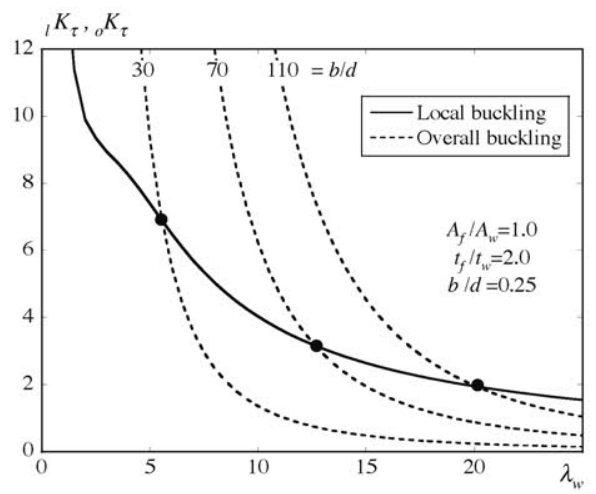

図11 座屈耐力曲線の例

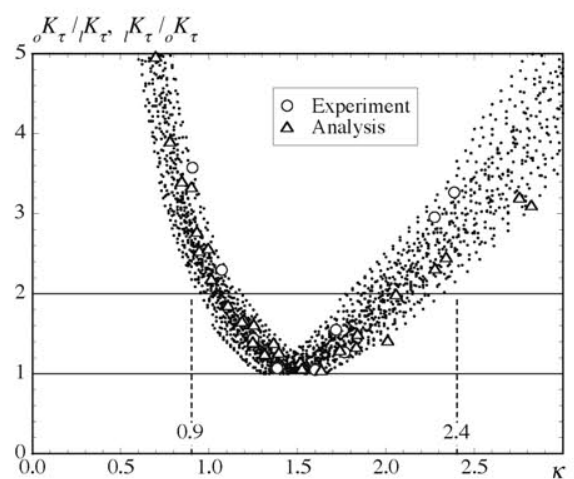

図12 座屈耐力比 
次に, 横座屈のみで塑性変形能力が決定するであるう める. ここでは, 弾性局部座屈耐力と弾性横座屈耐力の比を用いて 考察することとし, 文献16) と同様なエネルギー法による座屈解析を 行っている. 図 11 に弾性局部座屈耐力を定める座屈係数 $\left({ }_{1} K_{\tau}\right)$ と弾性 横座屈耐力を定める座屈係数 $\left({ }_{0} K_{\tau}\right)$ を, 横軸に辺長比をとって示す. ここに示す図は, 一例であり, 断面形状は図に示している.

これら座屈係数曲線は, 式 (3.2) 中に示すように, 弾性せん断座屈 耐力に対する座屈係数 $K_{\tau}$ を用いて表している.

$$
\tau_{c r}=K_{\tau} \frac{\pi^{2} E}{12\left(1-v^{2}\right)} \frac{1}{\left(d / t_{w}\right)^{2}} \ldots \ldots \ldots \ldots
$$

ここで, $\tau_{c r}$ : せん断座屈応力度, $E$ : ヤング係数, $v$ : ポアソン比, $d$ : ウェブせい, $t_{w}$ : ウェブ板厚である. なお, $\tau_{c r}$ の導出に関する詳 細は文献16)を参照いただきたい. 図中の印で示した点は限界辺長比 であり, 局部座屈耐力と横座屈耐力が等しくなる点である.

このようにして現実的な範囲を基本として様々なH形断面梁におい て求めた座屈係数を用いて, 縦軸に局部座屈係数と横座屈係数のう ち, 小さい方で大きい方を除した座屈耐力比を，横軸に $\kappa$ をり図 12 に示寸. 先の図10において, 局部座屈のみを考えればよいとして定 めた範囲である $\kappa>2.4$ のとき, 弾性局部座屈耐力と弾性横座屈耐力 の比は, おおむ放 2 以上を確保している. 横座屈のみを考えればよ い範囲についても同様に, 座屈耐力比が 2 以上を確保できれば良い として考えれば, $\kappa<0.9$ が得られる. 以上の仮定のもと, H形断面梁 の崩壊形式や塑性変形能力を考える上で連成座屈を考慮しなければ ならない範囲として， $0.9 \leq \kappa \leq 2.4$ を定めることが出来る.

この仮定を検証するために, 有限要素法による解析例を図13に示 す. 数值解析に用いた試験体のウェブ辺長比 $\lambda_{w}$ は10で統一し, 断面積 比と板厚比をパラメータとして 0.42 程度の $\lambda_{b}$ に対し, 様々なWF及び $\kappa$ をもつ試験体を選択した. 図14には図13の解析結果から得た最大耐 力時の塑性変形倍率 $\mu_{m}$ と $\kappa$ の関係を示す. 図13より， $\kappa$ の増加ととも に荷重変位関係にみる最大耐力後の劣化勾配は大きくなり, 最大耐 力時変位量は徐々に減少することがわかる，また，図14より 範囲境界線に相当する 0.9 を超えるとその後徐々に塑性変形倍率が低 下していく傾向が読み取れる. 以上の考察にもとづき, 図 9 におい て連成範囲を示寸直線を定めている.

\section{3 連成座屈を考慮した塑性変形能力評価指標の提示}

これまでの考察により, H形断面梁の崩壊形式には, 局部座屈ある いは横座屈のいずれか単独で決定される場合と, それらが関連し合

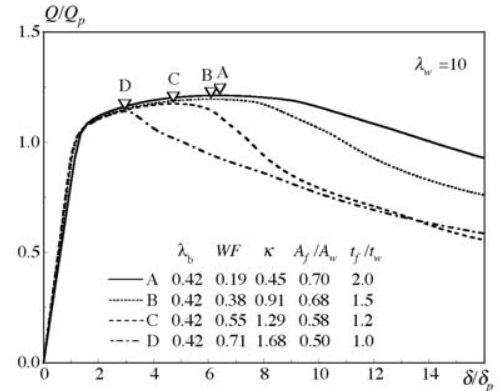

図13 連成座屈が影響する範囲の梁 の荷重変位関係

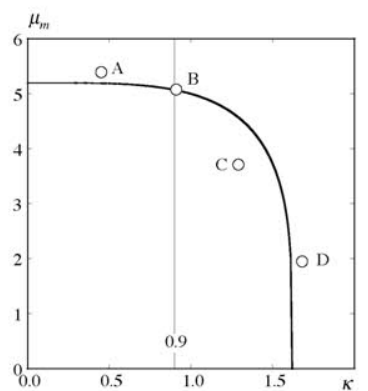

図14 塑性変形倍率の変化
いながら決定される場合があることを確認するとともに，崩壊形式 を分類するのに効果的な指標 $\kappa$ を提示した. さらにここでは, 局部座 屈から連成座屈, 横座屈によって崩壊する梁の塑性変形能力を統一 的に評価する手法について検討する.

それに先立ち, 局部座屈耐力指標である基準化幅厚比WFあるいは 横座屈耐力指標である一般化横座屈細長比 $\lambda_{b}$ のみで, H形断面梁の連 成座屈を含めた塑性変形能力が評価可能かどうかを確認する. 図15 の (a)，（b)はそれぞれWF， $\lambda_{b}$ により塑性変形能力を整理した図であ る.ここで, $W F, \lambda_{b}$ は式(2.1), 式(2.4)から求めている. ○は横座 屈を対象とした既往の研究25)～28) から収集したプロットであり, 局部座屈との連成が見られるものも含んでいる. なお, 既往の研究 の試験体の一般化横座屈細長比 $\lambda_{b}$ を算定するにあたり, 単純梁形式 の梁は, 横座屈に対して当該梁に取り付く梁からそり拘束を受ける と考え, 境界条件は一端単純支持, 他端そり拘束と見なしている.

ムは本論文における実験結果, 一は数值解析結果であり, 局部座屈 から横座屈まで様々な座屈性状のものを示している.ここに示すよ うに, 局部座屈耐力指標, 横座屈耐力指標のいずれか一方のみで は, 塑性変形倍率のばらつきが大きく, H形断面梁の塑性変形倍率を 統一的に評価することが出来ているとは言いがたい. ただし，これ までの研究成果等5), 10)からわかるように, 崩壊形式が明確な場合に は, 構成板要素の幅厚比あるいは一般化横座屈細長比で梁の塑性変 形能力はある程度評価可能である. 付録 3 には， $\kappa$ を用いてある程度 崩壊形式を分類した上で, 図15のプロットを抽出したものを示して いる.

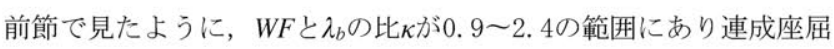
する梁は, 塑性変形能力の低下を考慮する必要がある. これを $\lambda_{b}-W F$
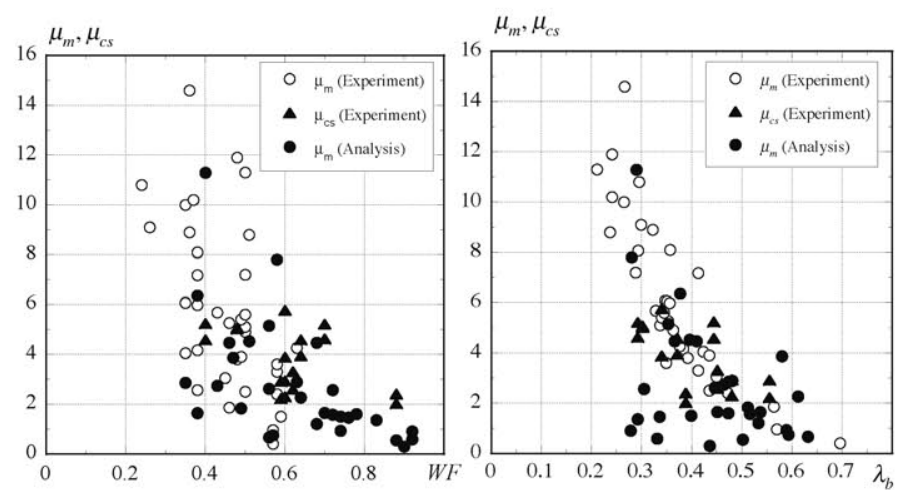

(a) 局部座屈耐力指標 $W F$ による評価 (b) 横座屈耐力指標 $\lambda_{b}$ による評価 図15 既往の座屈耐力指標による塑性変形能力評価

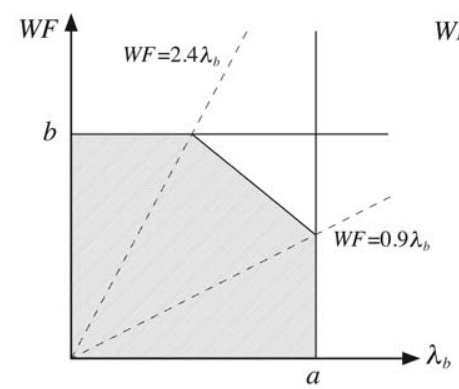

図16 塑性変形能力確保のため の領域概念図

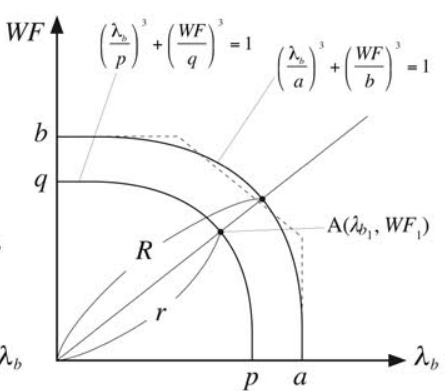

図17連成座屈を考慮したH形 断面梁の塑性変形能力 評価指標の導出概念 
平面上で，ある一定の塑性変形倍率を確保するために満足しなけれ ばならない領域として表現すると, 図16の陰を付けた範囲の様に考 えることができる，局部座屈のみ，あるいは横座屈のみを考えた設 計をする場合, ある塑性変形倍率を確保するためには, 前者の場合 $W F<b$, 後者の場合 $\lambda_{b}<a$ 一方の条件を満たせば良い. しかし, 連 成座屈を考慮する場合, $W F<b$ かつ $\lambda_{b}<a$ 満たす長方形領域の隅を, 連成効果を考慮して図のように低減する必要がある.

ここで本論文ではまず，図17に示すように，梁が全塑性耐力を確 保するための領域を三次棈円式で近似し，この曲線を連成座屈も考 慮にいれた塑性限界曲線と定義した上で, この曲線からの余裕度 $\Lambda_{c}$ $(=R / r)$ を考え, 塑性変形能力を評価する際の指標として用いる. こ の時, $W F$ に対する塑性限界值は 1 であり ${ }^{10)}, \lambda_{b}$ の塑性限界值 $\lambda_{b}$ は 0.6 である. このp $\lambda_{b}$ は文献 4$)$ に示されている下式(3.3) に, 本実験の モーメント勾配に対応する $M_{2} / M_{1}=0$ を代入して得られる值である.

$$
{ }_{p} \lambda_{b}=0.6+0.3\left(M_{2} / M_{1}\right) \quad \ldots \ldots(3.3)
$$

以上から， $\Lambda_{c}$ の一般式は次式で表される.

$$
\Lambda_{c}=\sqrt[3]{\left(\lambda_{b} / p \lambda_{b}\right)^{3}+W F^{3}} \cdots \cdots(3.4)
$$

このようにして得られる新規評価指標 $\Lambda_{c}$ を用いて梁の塑性変形能 力を評価した図が図18である， $\Lambda_{c}$ を評価指標とすることで座屈形式 に関わらず，図15とは異なり，ばらつきが少なくなっている。この ように, 本研究での考え方に基づく梁の塑性変形能力評価指標 $\Lambda_{c}$ は, 比較的精度良く統一的に塑性変形能力を評価することが可能で ある. $\Lambda_{c}$ で評価した塑性変形倍率の下限値は, 下式で与えられる.

$$
\mu=32\left(1-\Lambda_{c}\right)^{2} \ldots \ldots \ldots \ldots \ldots \text { (3.5) }
$$

また同図中には，文献 4), 文献10)で与えられているものと同じ塑 性変形倍率 $0,2 ， 4$ に対応した部材区分を示している. 現段階で は, データ量が少なく今後も検討していく余地はあるが, 区分に対 応した $\Lambda_{c}$ の值は概ね1.0， 0.75，0.65と設定できる.

最後に，このようにして定めた $\Lambda_{c}$ を用いて，図19のように， $\lambda_{b}-W F$ 平面上に構造区分を示すことができる.この図は， $M_{2} / M_{1}=0$ の場合 であるが，その他のモーメント勾配の場合も同様な図が描けること になる.

また，簡便には図19中の破線で示すように直線による構造区分を 用いてもよい. 図19の場合には，下式で表される.

$$
\left\{\begin{array}{lc}
W F \leq 0.54 \Lambda_{c}, \quad \lambda_{b} \leq 0.60 \Lambda_{c} & \kappa<0.9 \\
W F \leq 2.07 \Lambda_{c}-2.56 \lambda_{b} & 0.9 \leq \kappa \leq 2.4 \quad \cdots \cdots(3.6) \\
W F \leq \Lambda_{c}, \quad \lambda_{b} \leq 0.42 \Lambda_{c} & \kappa>2.4
\end{array}\right.
$$

\section{4. 結}

本論文では, 一端完全固定, 他端単純支持の境界条件下にあるH形 断面片持ち梁に対して, 繰返し載荷実験を行った. この結果, 各試 験体は局部座屈単独, 横座屈単独のものから, それらが混在する連 成座屈を生じたものまで, 様々な座屈形式で崩壊する梁の荷重変位 関係が得られた，連成座屈を生じる梁の繰返し載荷に特有の現象と して, 載荷履歴及び座屈変形が荷重正負方向で非対称なものとなる 場合があることを示した上で，そのような場合でも最大耐力点まで の履歴挙動は正負対称であり, 塑性変形倍率も正負でほぼ同程度の 値となることを明らかにした.

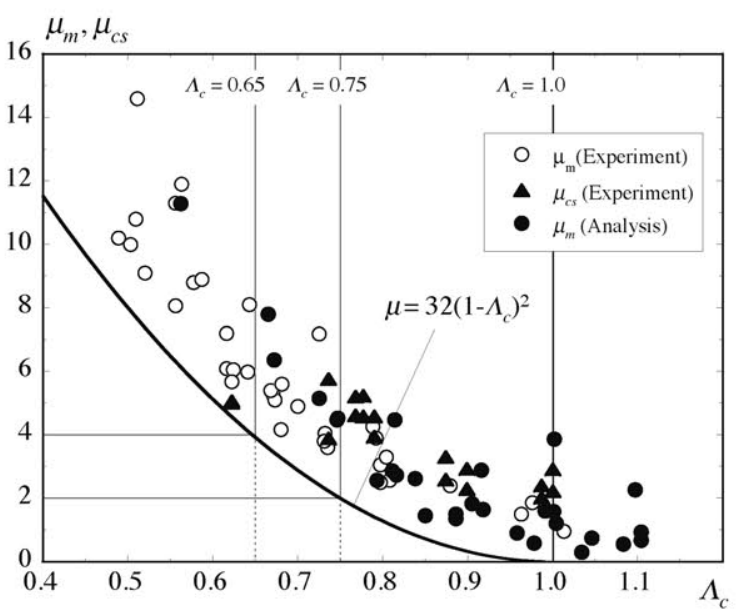

図18 連成座屈を考慮した指標による塑性変形能力評価

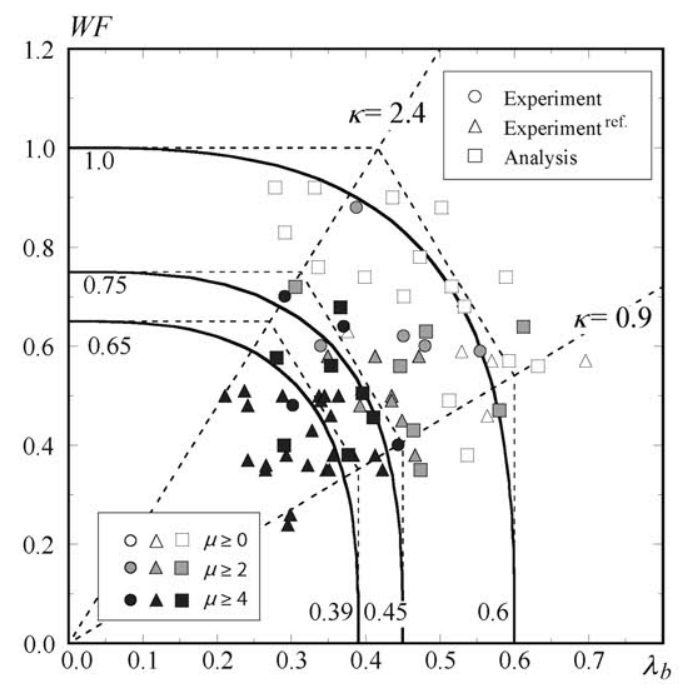

図19 連成座屈を考慮した構造区分案

また, 実験結果及び数値解析から得られた結果を用いて, 座屈性 状を分類し, 基準化幅厚比 $W F$ と一般化横座屈細長比 $\lambda_{b}$ で表される $\lambda_{b}$ $W F$ 平面上に局部座屈, 横座屈, 連成座屈が発生する可能性のある領 域を直線で区分した. さらに評価指標として, $W F と \lambda_{b}$ の比 $\kappa$ を提案 し, $0.9 \leq \kappa \leq 2.4$ の範囲を連成座屈範囲として定められることを示し た. 併せて, 同程度の $\lambda_{b}$ となる梁でも $W F$ が大きくなることで塑性変 形倍率が低下することを確認した。

これらの結果を受けて, 連成座屈が生じる梁の塑性変形能力評価 指標として, $\lambda_{b}$ - $W F$ 平面上で塑性限界を表す三次棈円曲線からの余裕 度として $\Lambda_{c}$ を定義し，これが局部座屈から横座屈までの幅広い座屈 性状を呈する梁に対して, 統一的に精度良く塑性変形倍率を評価で きることを示した．また梁の塑性変形倍率に応じた構造区分を提示 した.

今後は, さらに精度の良い座屈設計式につなげるべく，梁の繰返 し載荷におけるデー夕を増やしていく必要があり, それらの結果か ら, 本論文で提案した指標を用いた塑性変形能力評価の精度が向上 すると期待する. 


\section{謝辞}

本研究は，一般社団法人日本鉄鋼連盟「鋼構造研究・教育助成事

業」及び科学研究費補助金 (23360242)を受けて行ったものでありま

す．付して感謝の意を表します.

\section{参考文献}

1）日本建築学会 : 鋼構造設計規準 一許容応力度設計法一, 2005.9

2) 日本建築学会 : 鋼構造塑性設計指針, 2010.2

3) 日本建築学会：建築耐震設計における保有耐力と変形性能 (1990), 1990.10

4）日本建築学会 : 鋼構造限界状態設計指針・同解説，2010.2

5 ）日本建築学会 : 鋼構造座屈設計指針, 2009.11

6 ) 建築物の構造関係技術規準編集委員会 : 2007 年版建築物の構造関係技術規 準解説書, 2007.5

7 ）鈴木敏郎, 五十嵐規矩夫, 常木康弘 : せん断曲げ受ける $\mathrm{H}$ 形鋼梁の崩壊形 式と塑性変形能力に関寸る研究, 日本建築学会構造系論文集, No. 547, pp. 185 191，2001. 9

8 ）鈴木敏郎, 五十嵐規矩夫, 常木康弘：H形鋼梁の塑性変形性能に及ぼ寸端 部境界条件及び応力状態の影響に関する研究, 日本建築学会構造系論文 集, No. 563, pp. $185 \sim 192,2003.1$

9 ) 五十嵐規矩夫, 小田部敏明, 王 蓞 : ウェブ幅厚比の大きなH形断面梁の 塑性変形能力と座屈後繰返し挙動, 日本建築学会構造系論文集, Vol. 74, No. 646 , pp. $2345 \sim 2354,2009.12$

10）五十嵐規矩夫，末國良太，篠原卓馬，王 暲 : 鋼構造H形断面梁の耐力及 び塑性変形能力評価のための新規幅厚比指標と幅厚比区分, 日本建築学会 構造系論文集, Vol. 76, No. 668, pp. 1865～1872，2011. 10

11）今井克彦, 興田香二 : 局部座屈と横座屈が連成する溶接 $\mathrm{H}$ 形鋼の曲げ実験 （その1, その2），日本建築学会大会学術講演梗概集，pp. 1279～1282, 1984.9

12）興田香二, 今井克彦, 黒羽啓明, 小川厚治: 幅厚比の大きいH形断面曲げ 材の変形挙動予測に関する研究, 日本建築学会構造系論文集, No. 411, pp. 83〜96, 1990.5

13）鈴木敏郎，小河利行，末岡利之：崩壊機構の制御による勒性改善効果を考 慮したH形鋼梁の座屈補剛に関寸る研究, 日本建築学会構造系論文集, No. 480 , pp. $161 \sim 170,1996.2$

14）小野徹郎，石田交広，土方和己：連成座屈を考慮した鋼構造梁部材の横座 屈補剛に関する研究, 日本建築学会構造系論文集, No. 533, pp. 159〜 166, 2000. 7

15）劉 大偉, 金尾伊織, 中島正愛 : 繰返し載荷を受けるH形鋼梁の塑性変形 能力に及ぼす局部座屈の影響, 鋼構造論文集, 第 10 巻, 37 号, pp. 61 $70,2003.3$

16）五十嵐規矩夫, 王 轁 : 曲げせん断力を受けるH形断面梁部材の連成座屈 解析及び座屈耐力算定法, 日本建築学会構造系論文集, No. 623, pp. 135 142, 2008. 1

17）五十嵐規矩夫, 王 蓞 : 連成座屈を考慮したH形断面梁部材構成板要素の 幅厚比制限值評価法, 日本建築学会構造系論文集, Vol. 73, No. 629, pp. 1117 1184, 2008. 7

18）加藤 勉，秋山 宏 : 鋼構造部材の耐力（その4），日本建築学会論文報告

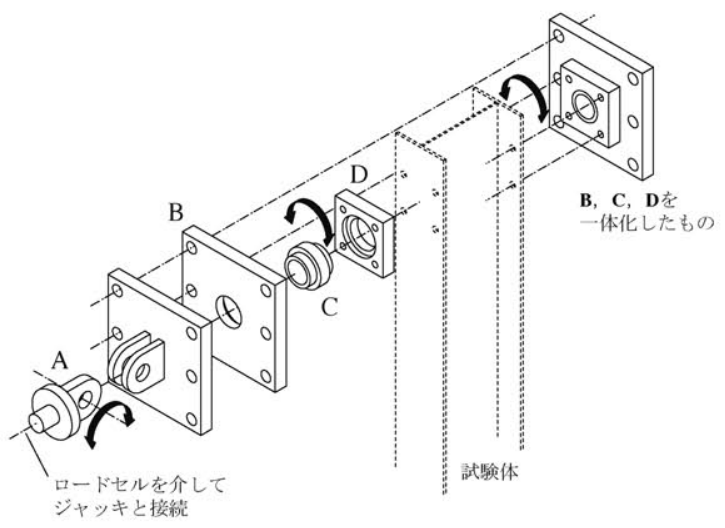

付図 1 載荷点機構図
集, No. 151 , pp. $15 \sim 20,1968.9$

19）加藤 勉, 秋山 宏, 帯 洋一: 局部座屈を伴う $\mathrm{H}$ 形断面部材の変形, 日本 建築学会論文報告集, No. 257 , pp. 49 58, 1977.7

20）日本建築学会 : 建築物の耐震性能評価手法の現状と課題 -限界耐力計算 . エネルギー法・時刻歷応答解析-, 2009.2

21）木村祥裕：局部座屈崩壊型 $\mathrm{H}$ 形鋼梁の塑性変形性能と累積塑性変形性能に 及ぼす載荷履歴特性の影響 一片持ち梁形式の載荷実験データベースの構築 -, 日本建築学会構造系論文集, Vol. 76, No. 664, pp. 1143 1151，2011. 6

22）井戸田秀樹，松野 巧，小野徹郎：横座屈で耐力が決まる一端曲げH形鋼 梁の繰返し履歴モデル，日本建築学会構造系論文集，Vol. 76, No.669, pp. 1981〜1988, 2011. 11

23）鈴木敏郎，木村祥裕 : H形断面の横座屈に対する柱梁接合部による反り拘 束の影響, 日本建築学会構造系論文集, No. 537, pp. 115 120, 2000. 11

24）五十嵐規矩夫, 鞆 伸之, 王 塪 : H形断面梁の横座屈耐力に与える端部境 界条件及びモーメント勾配の影響係数, 日本建築学会構造系論文集, Vol. 76 , No. 670 , pp. $2173 \sim 2181,2011.12$

25）鈴木敏郎，小野徽郎：塑性設計梁に対する実験的研究（2）モーメント勾配 をもつ梁, 日本建築学会論文報告集, No. 171, pp. $31 \sim 36,1970.5$

26）鈴木敏郎，小野徽郎：高張力鋼の塑性設計に関する研究 塑性設計梁に関 寸る実験的研究 (5)，日本建築学会論文報告集，No. $219 ，$ pp. 39〜 45, 1974.5

27）鈴木敏郎，小野徽郎，西田芳宏，加藤征宏 : 鉄骨梁の断面形状と変形能力 に関する実験, 日本建築学会大会学術講演梗概集, 構造系 49, pp. 897〜 $898,1974.8$

28）宇田川邦明，最相元雄，高梨晃一，田中 尚：一方向載荷を受ける $\mathrm{H}$ 形鋼 梁の塑性横座屈実験, 日本建築学会論文報告集, No. 212, pp. $23 \sim 36$, 1973. 10

\section{付録 1 載荷点の機構と境界条件}

ここでは，本文図 2 に示した載荷点治具及び境界条件との対応について説明 する. 付図 1 に, 載荷点の機構図を示す. 外側板のB，ベアリング 1 とベアリ ング 2 及びその内部にある心棒からなるCと内側板のDから構成される治具によ りフランジの面内回転（部材としては弱軸回りの回転）が許容される.この治 具は，上下梁フランジにボルトによりそれぞれ接合されており，上下梁フラン ジの面外回転を個別に許容する機構となっている.これにより断面のそりを拘 束しない. なお, Bの梁面外方向の移動は別途治具により拘束されている.

また，B〜Dからなる 2 組の治具が梁を挟んだ上で，梁の面内回転を許容する ピンAとPC鋼棒により接続されている.このAの先にロードセルを介して加力用 ジャッキが接続されており，そのジャッキ他端にも面内回転を許容するピンが 配され, 反カフーレムに取付けられている.これにより, 梁の材軸方向変位が 許容されている，これらの組合せにより，載荷点において単純支持の境界条件 を再現している

\section{付録 2 数值解析概要}

本研究における数值解析には, 有限要素法プログラムABAQUS/Standard Ver. 6.8 使用した．使用した要素は 4 節点シェル要素である. 実験結果との比較 における数值解析モデルの断面形状等は実測寸法を用いている. パラメトリッ クな解析においては, 梁せい, 梁幅, 材長を適宜変化させている. 板厚に関し ては，実験で使用した板厚から適宜選択しているため，材料データは，板厚毎 に引張試験結果から算出したものを用いている.

要素分割は，ウェブ板要素を梁せい方向に12分割，フランジ板要素を幅方向 に6分割し，材長方向にはそれぞれウェブ辺長比を 12 倍した数で分割してい る.これは, 各要素を極力正方形に近づけるためである. 対象としている忍力 状態は，片持ち梁形式の応力状態であり，それぞれの端部は一端を完全固定 （全節点の全自由度を拘束），他端にはスチフナを設け，その重心部節点の梁 としての弱軸方向変位及び材軸回り回転を拘束している. 大変形解析に先立ち 固有值解析を行い, 得られた座屈固有値の小さい方から 2 つに対応する座屈 モードを用いて, それぞれの座屈波形の最大值が $0.05 \mathrm{~mm}$ となるうに初期不整 を与えている. なお残留応力は考慮しておらず, 初期応力は与えていない.

本文節3.2図10で曲げねじれ変形を拘束した解析を行い, その結果を図10に 示している.この解析の場合, 固定端側から梁せい分, 材長の $1 / 4,1 / 2$ の位置 でウェブとフランジの接合線上の節点において，断面弱軸方向の変位のみを拘 束している.あわせて梁のせん断スパン比が 12 を超える場合には, 梁せい分の 2 倍の位置でも横変位を拘束している。

材料データは引張試験より得られた応力度ひずみ度関係を用いて作成してい る. ヤング係数, 降伏応力度は, 表 1 に示寸值を用い, 塑性化後以降は, 真応 
力真ひずみ関係に変換し, 明確な降伏棚を有するものについては降伏棚部を削 除している.

このようにして行った数值解析結果と一方向単調載荷の実験結果を比較した ものが, 本文図 7 であり, 両者は概权対応していることから, 本研究で用いた 数値解析法は妥当なものであると判断した.

\section{付録 3 既往の座屈耐力指標による塑性変形能力評価}

本実験での試験体, 数值解析対象, 既往の研究から収集した試験体を含め て, 本論文で対象とした梁のКは, 約 $0.74 \sim 3.4$ の間にある. 節 3.2 から, 梁の 挙動を考える場合に連成効果を考慮する必要がある範囲は，0.9 2.4である.

この範囲より大きい範囲が局部座屈により崩壊する範囲, 小さい範囲が横座屈 により崩壊する範囲である.ただ。この範囲の試験体のみを扱うと該当する個

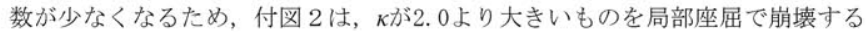

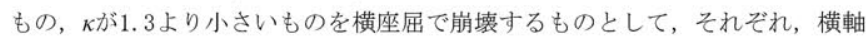
にWF，衴をとって本文図15と同様に表現したものである.梁の塑性変形倍率 は，付図 2 の方が本文図15に比較してWFや $\lambda_{b}$ のみで概敉評価できている。した がって， $\kappa$ を用いてそれぞれの崩壊形式を単独で扱えるように分類すれば，そ の範囲でWFや
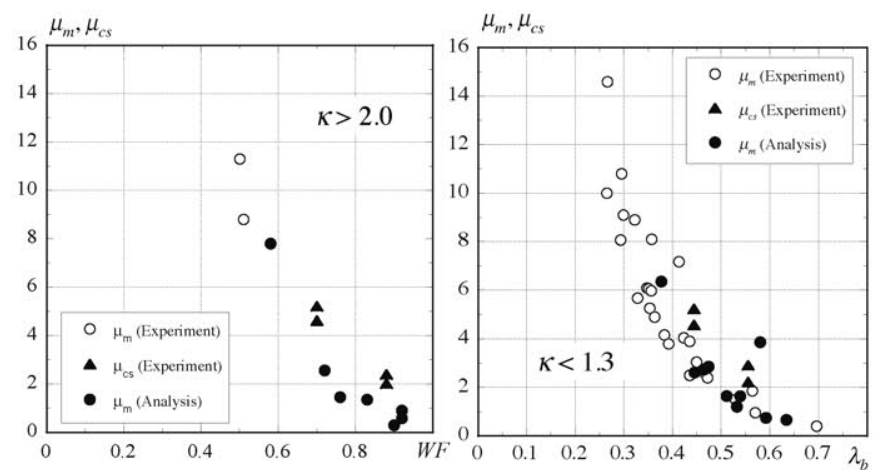

(a) 局部座屈耐力指標 $W F$ による評価

(b) 横座屈耐力指標 $\lambda_{b}$ による評価 付図 2 既往の座屈耐力指標による塑性変形能力評価

（2011年12月 8 日原稿受理，2012年 5 月 8 日採用決定） 